\title{
14-3-3 Protein Epsilon
}

National Cancer Institute

\section{Source}

National Cancer Institute. 14-3-3 Protein Epsilon. NCI Thesaurus. Code C101118.

14-3-3 protein epsilon ( $255 \mathrm{aa}, \sim 29 \mathrm{kDa}$ ) is encoded by the human YWHAE gene. This protein plays a role in signal transduction. 